TRADUÇÃO

\title{
Pensamentos de um espírito reto e sentimentos de um coração virtuoso e Fragmentos Diversos, de Jean-Jacques Rousseau
}

\author{
Tradução, Apresentação e notas: Rafael de Araújo e Viana Leite ${ }^{1}$
}

\begin{abstract}
Resumo: Tradução, apresentação e notas de dois textos de Jean-Jacques Rousseau, a saber, os Pensamentos de um espirito reto e sentimentos de um coração virtuoso, assim como os chamados Fragmentos diversos, ambos pertencentes à Miscelânea de literatura e de moral, conforme classificação do segundo Tomo das Obras Completas de Rousseau (Gallimard, 1964).

Palavras-chave: Rousseau - Fragmentos - Miscelânea - Tradução
\end{abstract}

\section{Apresentação da tradução}

O filósofo genebrino Jean-Jacques Rousseau (1712-1778) produziu uma obra multifacetada cuja importância foi reconhecida ainda em vida. A posteridade de sua reflexão também é digna de nota e passa pela Revolução francesa, pelo romantismo, pela filosofia política contemporânea e também pela educação. Trata-se, além disso, de um filósofo celebrado, mas igualmente criticado por obras como o Emílio (1762), o Contrato social (1762), ambos proibidos na França e em Genebra quando de sua aparição, e as Confissões, divididas em doze Livros, publicadas pela primeira vez somente em 1782.

No segundo Tomo das suas obras completas, editado pela Gallimard em 1964, é apresentado um conjunto de textos menos conhecidos. ${ }^{2}$ São esboços, anotações e frases esparsas em papeis guardados pelo autor que suscitam a curiosidade dos leitores e podem auxiliar nos estudos sobre a sua filosofia. Assim, entre faturas referentes à lavagem de roupas, cartas e listas de endereço, encontra-se um material filosoficamente diverso, de valor desigual, intitulado pelos editores como Miscelânea de literatura e de moral.

Traduz-se pela primeira vez em português dois desses textos, a saber, os Pensamentos de um espirito reto e sentimentos de um coração virtuoso, compostos por setenta e sete pensamentos, e os chamados Fragmentos diversos, a saber, quarenta e seis excertos conservados pela biblioteca de Neuchâtel. ${ }^{3}$ Esse material possui textos de tamanhos distintos, contemplam temas variados e foram redigidos em datas diferentes.

A história da publicação dos Pensamentos de um espirito reto e sentimentos de um coração virtuoso tem caminhos editoriais tortuosos. A anedota em torno de como a obra veio a lume é inusitada e gera dúvidas sobre a autoria atribuída a Jean-Jacques Rousseau. Ela aparece pela

\footnotetext{
${ }^{1}$ Professor colaborador na Universidade Estadual do Oeste do Paraná (UNIOESTE), Campus Toledo - PR. Possui graduação, mestrado e doutorado em Filosofia pela UFPR, tendo realizado estágio na França, na Universidade de Rennes I. Realizou estágio de Pós-Doutorado (PNPD) na UFPA em 2019. É membro da ABES XVIII, do GIP-ROUSSEAU e do Grupo de Estudos das Luzes - UFPR. Atualmente é Professor colaborador na UNIOESTE.

2 ROUSSEAU, Euvres Complètes, T. II, Org. Bernard Gagnebin e Marcel Raymond. Paris: Gallimard, 1964.

${ }^{3}$ Fragments divers (1964b, pp. 1320-1332), Pensées d'un esprit droit, et sentiments d'un cour vertueux (1964d, pp. 12991314). Os textos da Miscelânea de literatura e de moral foram estabelecidos e comentados por Charly Guyot.
} 
primeira vez em uma publicação datada de 1826, única fonte do texto, mais precisamente em uma edição sob responsabilidade de Mathieu-Guillaume-Thérèse Villenave (1762-1846). ${ }^{4} \mathrm{O}$ editor em questão, que junto com Depping foi responsável por uma edição das obras completas de Rousseau em 1817, afirmou ter encontrado o manuscrito autógrafo depois desse material ter permanecido com pessoas incapazes de reconhecer a sua autoria. É realmente uma sorte grande deparar-se acidentalmente com um manuscrito desconhecido de Rousseau, algo ressaltado pela Apresentação do texto redigida por Villenave: "um manuscrito desconhecido de Jean-Jacques Rousseau: (...) que descoberta para a literatura francesa!"'5. Contudo, o leitor mais ressabiado logo se questiona caso não teria sido sorte em demasia para não ter sido tudo orquestrado.

A essa suspeita, antecipada pelo editor, ele responde oferecendo o manuscrito autógrafo para quem quisesse conferir, o que não foi feito pelas edições posteriores das obras de Rousseau. Cita-se ainda o Livro XII das Confissões, tanto como epígrafe na capa da obra publicada por Villenave quanto na sua Apresentação dos Pensamentos de um espirito reto $e$ sentimentos de um coração virtuoso. Trata-se de uma passagem estratégica para o editor porque nela relata-se o furto de papeis e de esboços pertencentes a Rousseau, entre eles inclusive uma obra nunca terminada, chamada Moral sensitiva, ou o materialismo do sábio. Villenave afirma ter encontrado parte desses papeis furtados e oferece como prova a passagem mencionada das Confissões. Prova circunstancial, é verdade, pois o leitor pode tanto aceitar a hipótese levantada pelo editor quanto colocá-la em questão. Com efeito, a aproximação entre a Moral sensitiva, ou o materialismo do sábio proposta como sendo verossímil por Villenave ${ }^{6}$ poderia ser feita caso ele não tivesse lido as Confissões e o relato do furto? Certo mesmo é que não há nenhuma evidência capaz de comprovar essa hipótese, tampouco se o título foi dado pelo próprio Rousseau. Villenave afirma que ao manuscrito encontrado faltava o seu início e, além disso, não é possível saber se ele está completo.

Pode-se facilmente perceber o esforço de Villenave em corroborar a ideia de que o texto é realmente de Jean-Jacques Rousseau. Por exemplo, quando afirma que mesmo se o manuscrito não fosse autógrafo não seria possível desconhecer o autor ao proceder à leitura do texto ${ }^{7}$. No pensamento de número 42, há ainda uma nota conforme a qual "Todo o caráter de Rousseau está traçado aqui em algumas linhas"». Interessa notar como, em contrapartida, o editor da Miscelânea de literatura e de moral (Gallimard, 1964), Charles Guyot, opta pelo ceticismo quanto à autoria do texto, solicitando extrema cautela em sua leitura. Bem distintamente de Villenave, ele assevera: "Quase não encontramos aí [nos Pensamentos de um espirito reto e sentimentos de um coração virtuoso] o tom de Rousseau, as ressonâncias profundas do seu estilo". Não há menção de que Charles Guyot tenha tido acesso ao manuscrito referido por Villenave, cuja edição da obra é, com efeito, usada como texto base pela Gallimard. Ficase, portanto, como que entre a empolgação de uma descoberta interessante e a desconfiança quanto à real autoria dessas páginas.

\footnotetext{
${ }^{4}$ ROUSSEAU, Jean-Jacques. Pensées d'un esprit droit, et sentiments d'un cœur vertueux. Ouvrage inédit, imprimé sur le manuscrit autographe de l'auteur ; suivi d'un autre opuscule de Rousseau intitulé : Mœurs, Caractère. Paris: Fournier-Favreux, 1826.

${ }^{5}$ ROUSSEAU, Pensées d'un esprit droit, et sentiments d'un cœur vertueux, 1826, p. 5

${ }^{6}$ Cf. ROUSSEAU, Pensées d'un esprit droit, et sentiments d'un cour vertueux, 1826, p. 10.

${ }^{7}$ ROUSSEAU, Pensées d'un esprit droit, et sentiments d'un cœur vertueux, 1826, p. 11.

${ }^{8}$ ROUSSEAU, Pensées d'un esprit droit, et sentiments d'un cour vertueux, 1826, p. 40, nota.

${ }^{9}$ ROUSSEAU, "Pensées d'un esprit droit, et sentiments d'un cœur vertueux", 1964d, p. 1952.
} 
Recentemente foi publicada uma compilação das obras completas de Rousseau pela editora Slaktine (Genebra e Paris, 2012) responsável por trazer informações novas sobre o texto. Os Pensamentos de um espírito reto e sentimentos de um coração virtuoso aparecem no Volume 17 com Apresentação de Raymond Trousson. ${ }^{10}$ Nela, o comentador menciona o fato de que Théophile Dufour, um dos responsáveis por editar a correspondência geral de Rousseau, disse ter tido acesso ao manuscrito em 1850 e, ademais, disse ter reconhecido a letra do filósofo ${ }^{11}$, o que traz alguma legitimidade para o material. Atualmente, contudo, o manuscrito está desaparecido. Sem esse texto autógrafo, a dificuldade em relação à autoria da obra provavelmente não será facilmente resolvida, principalmente porque Rousseau nunca participou da compilação de suas obras completas, apesar de ter concebido esse projeto em 1758.

Como não se pode provar a autenticidade do texto, nem se pode tampouco provar a sua falsidade, cabe ao leitor fazer um uso cauteloso desses pensamentos: ora aceitando a autoria atribuída a Rousseau, aspecto pelo qual eles se tornam atraentes, mas para em seguida vislumbrar uma frase ou ideia estranha ao que conhece do filósofo genebrino, algo capaz de excitar a suspeita: eles saíram mesmo da pena de Rousseau?

Os Pensamentos de um espirito reto e sentimentos de um coração virtuoso, em número de setenta e sete, são escritos bem ao estilo de máximas ou aforismos, e gravitam em torno de temas como casamento, amor, felicidade, velhice, relação com o passado e, principalmente, sobre as paixões e a amizade. São vinte e três pensamentos diretamente ligados ao tema da amizade, tanto em seu aspecto positivo, isto é, sobre a sua importância e o modo como deve-se comportar com um amigo quanto, de outro modo, em sentido negativo, a saber, a propósito da fragilidade das relações humanas, traição, engodos e mentiras de pessoas falsas. Há ainda três pensamentos sobre o contexto adequado para dar conselhos, portanto ligados ao tema da amizade.

Sobre as paixões, há pelo menos dois pensamentos que ligam a submissão às paixões a uma prisão (pensamentos L e LXXI) e, além disso, explica-se o comportamento passional de pessoas inconsequentes (pensamento XXI), vãs (pensamento XXXVI), impertinentes (pensamento LIV), inconstantes (pensamento LXII), orgulhosas (pensamentos VIII, XX, XXXIV e LXIV) e com exagerada boa opinião de si (LVIII).

É interessante como esses aforismos, veiculados como se fossem os pensamentos de um espírito reto, parecem ligar-se essencialmente ao comportamento de pessoas dotadas de um espírito tortuoso. Mais do que isso, os sentimentos desse coração que se diz virtuoso são marcados pelas agruras provocadas por pessoas falsas: "Tentou-se em vão disfarçar seus objetivos e intenções secretos, a máscara cai cedo ou tarde" (Pensamento LXXV). Passagem carregada de negatividade e resignação, um pouco como na Nova Heloisa quando o personagem Saint-Preux se queixa dos parisienses, mais precisamente na Carta XIV da segunda Parte do romance: “Até aqui vi muitas máscaras, quando verei rostos de homens?”12. Atente-se ainda para o pensamento XV, quando Rousseau fala das pessoas dotadas de um "coração ruim" [mauvais ccur], expressão diametralmente oposta a "coração virtuoso" [cour

${ }^{10}$ ROUSSEAU, JEAN-JACQUES. "Pensées d'un esprit droit, et sentiments d'un cœur vertueux". In: CEuvres complètes. Édition thématique du tricentenaire. Org. Raymond Trousson e Frédéric S. Eigeldinger. Volume 17. Genebra: Slaktine, 2012.

${ }^{11}$ ROUSSEAU, "Pensées d'un esprit droit, et sentiments d'un coeur vertueux", V. 17, 2012, p. 417.

12 ROUSSEAU, "Nouvelle Hélö̈se”, 1964c, p. 236. 
vertueux], incorporada ao título da obra. O espírito reto do autor desses pensamentos parece ter dificuldade em não se concentrar precisamente nos espíritos tortuosos cujos corações carecem de virtude.

Os Fragmentos diversos tratam de vários temas e foram escritos em datas distintas. Conforme as notas presentes na edição da Gallimard, de 1964, alguns deles possivelmente remontam a 1758/1759 e outros a 1764. Entretanto, é difícil dizer com precisão o período em que foram redigidos e em qual projeto seriam inseridos ou se, de outro modo, não passam de anotações simplesmente rejeitadas pelo autor.

Alguns fragmentos são relativamente longos enquanto outros, por sua vez, não passam de duas linhas. Os cinco primeiros merecem destaque porque, pelo tema, possivelmente representam esboços para a preparação de um Prefácio que faria parte da edição das obras completas de Rousseau, projeto elaborado em 1758, mas nunca concluído, como já se disse anteriormente. Os fragmentos de número 6, 7, 8 e 9 tratam de assuntos ligados à elaboração do Discurso sobre as ciências e as artes, publicado em 1750. Fala-se, por exemplo, sobre as Academias, sobre os intelectuais, sobre os autores e sobre o estilo de escrita. Em outros fragmentos, Rousseau trata de temas como o uso proveitoso do tempo de vida das pessoas, mas igualmente de assuntos ligados à natureza/cultura e também ao princípio de prazer e dor responsável por conduzir o comportamento humano (fragmentos 21 e 32$)$.

Sobre o prazer e a dor, Rousseau é bastante explicativo, subdividindo, por exemplo, os tipos de prazer possíveis em um movimento argumentativo que pode, em alguma medida, fazer vislumbrar a corrente filosófica conhecida como utilitarismo. Os dois últimos fragmentos, lidando com questões teatrais, estão claramente inseridos em um contexto paralelo ao da Carta a d'Alembert, publicada em 1758. O leitor encontrará nesses fragmentos um material que pode esclarecer passagens já consagradas do filósofo ou ainda se deparar com temas e considerações sem muita ressonância em obras formalmente publicadas.

A tradução dos Pensamentos de um espírito reto e sentimentos de um coração virtuoso e dos Fragmentos diversos, interessa ainda notar, baseou-se na edição da Gallimard das obras completas de Rousseau (1964, Tomo II). Reproduzi as notas presentes nessa edição porque apresentam variantes, palavras e frases corrigidas ou anuladas pelo autor. Esse esforço tem como objetivo ajudar a ter uma ideia das opções consideradas por ele enquanto escrevia, além de iluminar questões estilísticas. Preservei parágrafos sem espaçamento ou palavras minúsculas em início de frase para explicitar o caráter esboçado de algumas passagens.

Ao leitor fica então o convite para entrar no escritório de Rousseau, revirar suas malas e conhecer parte do seu esforço de escrita, da sua procura pela melhor palavra ou expressão, compreender de modo mais aprofundado, enfim, os temas pelos quais ele se interessava e sobre os quais refletia. 


\section{Pensamentos de um espírito reto e sentimentos de um coração}

virtuoso

Jean-Jacques Rousseau

I

Acredita-se, ${ }^{13}$ geralmente, que é moralmente impossível ser feliz e, julgando por minha experiência, seria dessa opinião. Entretanto, minhas reflexões começam a me convencer de que a felicidade não é uma quimera quando é procurada em seu próprio interior e não fora de si.

É preciso, para encontrá-la, não ter nenhuma reprovação a se fazer e enxergar os defeitos e os vícios dos homens sem desejar-lhes mais mal por causa disso.

É preciso não odiar ninguém porque o ódio é um tormento para quem conserva essa paixão no coração. É suficiente desprezar e tolerar as crueldades e os ridículos. ${ }^{14}$

\section{II}

Se tivesse tido a força para renunciar a pessoa que me enganou, quando percebi pela primeira vez ter sido traído, teria poupado reprimendas a mim mesmo e novos crimes a ela. Porém, desejei explicações, ela me deu garantias com as quais fui ainda tolamente enganado e fiz com que acrescentasse múltiplas mentiras à perfídia da qual já era culpada. ${ }^{15}$

\section{III}

É bem suficiente ter contra mim os meus remorsos em relação ao passado: é preciso ao menos poupar-me o desprezo por mim mesmo em relação ao futuro. ${ }^{16}$

\section{IV}

Quando se age somente pelos motivos mesquinhos ligados ao amor pelo dinheiro, não se coloca jamais em suas ações nenhuma verdade, nem em seu zelo nenhuma afeição verdadeira. ${ }^{17}$

\footnotetext{
${ }^{13} \mathrm{Na}$ edição de 1826, de Matthieu Villenave, lê-se “Acredita-se, muito geralmente (...)". A edição de 2012, sob direção de Marcel Raymond e Frédéric S. Eigeldinger (Slaktine, 2012) baseia-se naquela de 1826 e preserva a palavra faltante na edição da Gallimard (1964). Nota do tradutor (doravante sinalizada N.T.).

${ }^{14}$ Sobre o tema da felicidade, privilegiado neste fragmento ver, por exemplo, a Carta II das Cartas morais, cujo início afirma "O objetivo da vida humana é a felicidade, mas quem de nós sabe como atingi-la?" (ROUSSEAU, 2005, p. 146). [N.T.].

${ }^{15}$ Rousseau fala de Denis Diderot? Difícil afirmar categoricamente, mas certo é que durante muito tempo ele foi seu amigo até que, em 1758, romperam formalmente a amizade. [N.T.].

${ }^{16}$ Rousseau, quem sabe, se refere ao caso de uma fita decorativa furtada por ele quando tinha dezesseis anos. Quando confrontado, ele acusou falsamente a camareira Marion de ter cometido o delito. O episódio é relatado na sua obra As confissões, Livro II. Na Quarta caminhada da obra intitulada Devaneios de um caminhante solitário, ele volta a falar desse acontecimento traumático. Nota do tradutor. Villenave escreve uma nota em que se diz: “Como Rousseau era digno de lástima! E que confissão ele já não fazia dele mesmo” (ROUSSEAU, 1826, p. 15).

${ }^{17}$ Rousseau foi um crítico ferrenho do luxo e do dinheiro. No Livro I das Confissões, ele afirma, com efeito, que nunca sofreu tentação por dinheiro (1959, p. 35). Cito, a título de ilustração, duas passagens presentes nas Considerações sobre o governo da Polônia, mais especificamente, no Capítulo 11: "Não se pode fazer os homens agirem senão por seu interesse, eu o sei, mas o interesse pecuniário é o pior de todos, o mais vil, o mais próprio à corrupção" (ROUSSEAU, 1964a, p. 1005). No mesmo capítulo, um pouco adiante, afirma-se ainda: "Procurai
} 
Há somente um meio seguro para destruir em seu coração uma paixão tão violenta quanto o amor: separar-se da pessoa amada. A sua presença é um alimento contínuo fornecido a um fogo mal apagado.

\section{VI}

Irão vos sobrecarregar com promessas solenes de estima e de reconhecimento enquanto esperam algo de vós; porém, se acreditarem não ter mais nada a esperar, vos abandonarão sem pudor e sem arrependimento.

\section{VII}

As leis divinas e humanas estabeleceram entre as pessoas casadas a superioridade do homem e a dependência da mulher. Porém, para engajá-la a se submeter sem repugnância é preciso que o marido não exija dela nada irrazoável.

Nada é mais perigoso do que a autoridade nas mãos de quem não sabe fazer uso dela.

\section{VIII}

O orgulho é o vício que menos perdoamos, ele fere essencialmente o amor-próprio. O orgulhoso não pode ser nem afável e nem agradecido, somente rebaixando-nos é que procura satisfazer a sua altivez.

Teme-se o orgulho dos grandes senhores porque podem prejudicar, despreza-se o das pessoas sem crédito e sem poder porque a sua tola arrogância não pode levar prejuízo a ninguém.

\section{IX}

O comércio da vida civil exige ajudas mútuas e bondades recíprocas. Não desejar jamais se encarregar com responsabilidades e sempre desejar que outrem o faça é o projeto mais injusto e o mais extravagante.

\section{$\mathbf{X}$}

Sem religião, não pode haver nem verdadeira probidade e nem felicidade sólida.

Mas poucas pessoas possuem uma ideia justa da religião. Faz-se comumente com que consista em práticas exteriores, e não se cumpre nenhum dos deveres essenciais prescritos por ela. Sem dúvida, é necessário observar os preceitos da igreja, mas não se imagine que já está tudo feito ao observar o serviço divino e ao resmungar algumas preces com as quais o coração não se identifica.

Só se possui religião quando não se faz contra os outros aquilo que não gostaríamos que fizessem contra nós, e quando se faz por eles aquilo que gostaríamos que fizessem por nós.

A verdadeira religião é a verdade, a caridade, a beneficência, a humildade, a doçura no caráter e nos procedimentos. Todo exercício religioso que não é fundado nesta base é somente ilusão e hipocrisia.

em todo país, em todo governo e em toda a terra. Não encontrareis um grande mal em moral e em política no qual o dinheiro não esteja metido" (ROUSSEAU, 1964a, p. 1006). [N.T.]. 
As pessoas que nunca perdoam nada dos outros pretendem que tudo thes seja perdoado.

Para viver em paz, seria preciso não se ofender com nada e não ofender ninguém.

\section{XII}

A amizade é o tesouro mais precioso e o mais raro da vida. Um verdadeiro amigo divide dos meus prazeres e das minhas aflições, tolera as minhas falhas e não tem para com elas uma covarde complacência. Ele não me faz contínuas promessas solenes de zelo, mas me mostra em todas as suas ações uma ligação terna e sincera. Ele deseja o que é de meu interesse, e o procura de preferência ao seu.

\section{XIII}

Quando nos aproximamos da velhice é preciso se ocupar apenas com o cuidado de fazer um melhor uso do tempo que resta a viver, o que não foi feito com o aquele que foi vivido, e pensar em sua existência somente como preparação para perdê-la em breve. ${ }^{18}$

\section{XIV}

Quando se ama apenas a si mesmo, e esse sentimento é demasiadamente comum, tornamo-nos fardos para os outros sem sermos úteis a ninguém.

\section{XV}

Os caracteres orgulhosos e obstinados são igualmente incapazes de dar ou receber conselhos: eles seguem apenas as impressões de sua crueldade e de seu coração ruim.

\section{XVI}

É a força da paixão que faz mais frequentemente tolos em matéria de amor do que a fraqueza do espírito.

\section{XVII}

Quando se está determinado a romper com alguém que foi amado, não se deve, em absoluto, refletir nem sobre a resolução nem sobre os motivos que levam a tomar essa decisão: é preciso ocupar-se com qualquer outra coisa que não tenha ligação com a pessoa amada. Essa divisão enfraquecerá a paixão, fornecerá coragem e forças para vencê-la inteiramente e sem recaída. Cura-se completamente apenas quando não se deseja e não se teme mais nada da pessoa amada.

\section{XVIII}

As mulheres, em sua maior parte, são semelhantes aos enigmas: interessam quando não são desvendadas, mas desde que sejam conhecidas elas cessam de agradar. ${ }^{19}$

\footnotetext{
${ }^{18}$ Charles Guyot, em nota para a edição da Gallimard (1964, Tomo II, p. 1953. Nota I da p. 1302) aponta com precisão como temos aqui o fio condutor do que será tratado na Terceira caminhada dos Devaneios de um caminhante solitário.

${ }^{19}$ Charles Guyot, em nota, levanta a questão se um pensamento como esse poderia ser verdadeiramente de Rousseau (1964, Tomo II, p. 1953. Nota II da p. 1302). Villenave, por sua vez, coloca em nota que "Nenhum
} 


\section{XIX}

Os bens e os males experimentados pelo sábio contribuem para a sua perfeição. É assim que o sol e a chuva concorrem para fertilizar a terra.

\section{XX}

Quando se é orgulhoso e obstinado, não é por falta de luzes e de conhecimentos, mas por defeito de sentimento. Deixa-se o caminho da razão, da justiça e do reconhecimento. Uma falsa vergonha impede que se retorne a ele, e quanto mais se espera, mais se fica revoltado contra a verdade e a decência. O partido mais sábio para se tomar com pessoas dotadas desse caráter é o de guardar o silêncio e deixá-las voltarem a si por elas mesmas, caso a depravação do coração não as mantenha de modo absoluto em sua obstinação.

\section{XXI}

A inconsequência faz falar e agir sem reflexão. Se as pessoas dotadas desse defeito quisessem se lembrar de tudo o que disseram e fizeram, seriam humilhadas pelas imprudências, pelas indiscrições e pelos erros de conduta dos quais se tornaram culpadas.

O inconsequente fala sempre mal e não escuta jamais o que lhe é dito ou escuta mal.

\section{XXII}

Nada é tão baixo e tão covarde como procurar se justificar por meio da mentira. Um mentiroso é alvo de desprezo público e contrai, pelo hábito de querer enganar os outros, aquele de enganar a si mesmo.

Ligamo-nos uns aos outros pela fala que deve ser a intérprete de nossos pensamentos e de nossos sentimentos, mas se ela perdeu todo o seu crédito e toda a confiança, todas as ligações da sociedade e do comércio da vida são rompidas.

Mesmo a verdade passa por impostura na boca de um mentiroso.

\section{XXIII}

Nada deve ser mais precioso de que uma boa reputação. Acreditar-se-ia ser o contrário caso se julgasse pela facilidade com a qual os homens lhe sacrificam em favor de um vil interesse.

\section{XXIV}

Quando se examina a maneira pela qual os homens e as mulheres vivem uns com os outros, somos tentados a pensar que foram criados tão somente para se atormentarem e se destruírem reciprocamente.

\section{XXV}

Vejo duas pessoas que parecem extremamente ligadas pela amizade. Se eu dissesse a cada uma delas todo o mal que me disseram uma da outra, passariam a detestar-se ainda mais do que parecem se gostar.

escritor falou tão mal das mulheres como Rousseau, e nenhum escritor excitou mais entusiasmo entre as mulheres: é que ele tinha amado demais" (ROUSSEAU, 1826, p. 23). 


\section{XXVI}

É inútil e frequentemente perigoso dar conselho a alguém que, animado pelo ardor de uma paixão, escuta tão somente os seus movimentos.

Para aconselhar bem é preciso conhecer o caráter da pessoa necessitando de conselho e esperar as circunstâncias favoráveis para fazer com que o receba, caso não seja com docilidade, ao menos sem azedume.

Deve-se ter em mente, ao aconselhar, apenas agir em favor do benefício dos outros e não misturar nenhuma motivação pessoal a esse objetivo.

\section{XXVII}

Suporta-se pacientemente ser repreendido às vezes quando se merece costumeiramente ser elogiado.

\section{XXVIII}

Se alguém me confia um segredo, ainda que possa ser pouco importante, devo guardá-lo escrupulosamente. Porém, o homem sábio não deve fazer confidências a não ser em caso de necessidade urgente e com muita circunspecção.

Deve-se confidenciar apenas a um amigo, mas pode-se garantir que ele jamais deixará de sê-lo? Se digo um segredo a alguém porque acredito que seja um amigo, ele acreditará estar igualmente autorizado a revelá-lo a um terceiro, considerado também como seu amigo; este último o contará a um quarto e eis o segredo da comédia.

\section{XXIX}

O despeito causado por uma inclinação desprezada, ou quando a pessoa amada não corresponde em absoluto a essa inclinação, exige somente ser apaziguado. E gostaria, se infelizmente me encontrasse neste caso, que me provassem a injustiça e a falta de fundamento das minhas suspeitas. Estou bem longe de buscar o crime, desejaria tão somente ver a inocência.

De resto, o despeito nunca curou uma paixão. Essa cura deve ser a obra da separação e da ausência: não há outro remédio.

\section{XXX}

Nada alivia mais seguramente as tristezas interiores do que a liberdade de se queixar e de tirar consolação do seio de um amigo. Porém, há pessoas suficientemente infortunadas para não ter nem mesmo esse recurso. ${ }^{20}$

\section{XXXI}

A base mais sólida do repouso e da felicidade é fazer com que não dependam daquilo que não depende de nós.

\footnotetext{
${ }^{20}$ Villenave escreve em nota que "Rousseau frequentemente colocou-se, em seus escritos, entre aqueles suficientemente infortunados, e esse recurso sempre lhe foi tolhido por conta de sua imaginação e por suas desconfianças" (ROUSSEAU, 1826, p. 31).
} 
Seria uma loucura empreender a correção dos vícios de outrem e ser muito vivamente afetado por eles. É preciso se limitar a não os ter em si mesmo e, de resto, a tomar o tempo como ele vem, e os homens por aquilo que valem.

\section{XXXII}

Não temos em absoluto estudo mais essencial e mais salutar do que aquele referente a nós mesmos. Devemos nos aplicar a conhecer o que nos é pessoalmente específico e não o que nos é estranho. É preciso nos instruir a respeito de nossas falhas para corrigi-las e a respeito das dádivas que a natureza colocou em nós para regrar o seu uso, o objeto de sua finalidade. ${ }^{21}$

\section{XXXIII}

Por pouco que se deseje de boa-fé examinar a si mesmo, percebe-se facilmente o pouco que se vale e não se é tentado a ser altivo e orgulhoso. Não se estima além do que convém, e purifica-se seu espírito e seu coração do perigoso veneno da vaidade e da altivez.

\section{XXXIV}

Nunca reparastes no modo como os orgulhosos se conduzem em relação a outrem? Haveis notado o desdém com que vos escutam, a arrogância com a qual eles não vos respondem senão com um sorriso zombeteiro ou alguma intenção insultante? Enrubesce-se, por eles, por causa de sua grosseria impudente. Somente eles não enrubescem e, se não excitam muita indignação, o que acontece mais comumente, são ao menos motivo de piedade.

\section{XXXV}

É preciso colocar uma grande diferença entre os defeitos do espírito, da imaginação, do humor e os vícios do natural e do coração. Os primeiros produzem caprichos, leviandades e teimosias passageiras. Os outros, mentiras, dissolução, ${ }^{22}$ ingratidão, uma obstinação insolente e indomável. Perdoa-se facilmente os primeiros, jamais poupa-se os outros.

\section{XXXVI}

As pessoas vãs e que se desconhecem teriam a ganhar caso tivessem a coragem de tirar delas mesmas o véu que têm diante dos olhos e de se lembrarem, de boa-fé, o que são e de onde saíram para chegar no ponto em se encontram! Elas então se julgariam conforme as luzes da equidade e as regras da razão. Por uma consequência necessária, estariam bem afastadas de pensar que tudo lhes é devido e que não devem nada a outrem.

\section{XXXVII}

Sempre quis um amigo que fosse um confidente a quem pudesse abrir a minha alma, um conselho nas minhas deliberações, um consolador em meus infortúnios, um outro de mim mesmo pelas ligações de ternura e de fidelidade. Acreditei, enfim, ter encontrado esse

\footnotetext{
${ }^{21} \mathrm{Na}$ edição de 1826, sob responsabilidade de Villenave, lê-se: “(...) para regrar seu uso, o objeto $e$ a finalidade”. A edição da Slaktine mantém a formulação da frase como aparece em 1826.

${ }^{22} \mathrm{Na}$ edição de 1826, sob responsabilidade de Villenave, lê-se "dissimulação" e não "dissolução". A edição da Slaktine preserva a palavra "dissimulação".
} 
tesouro inestimável, porém me enganei. A traição que experimento me ensinará a não me fatigar à procura de uma quimera.

\section{XXXVIII}

Ofereceram-me as mais fortes promessas solenes de apego, elas foram acompanhadas das expressões mais afetuosas, dos juramentos mais lisonjeiros e das mais sedutoras demonstrações. Porém, tudo isso não passava de uma linguagem que parecia tudo dizer e que não significava nada. O coração tinha o ar de entregar-se a sentimentos ternos e sinceros e, no fundo, não sentia nada. Penetrei enfim através de todas essas aparências, reduzi a fala ao seu verdadeiro sentido. Apreciei os testemunhos mais especiosos em seu justo valor e vi somente indiferença, cupidez e perfídia.

\section{XXXIX}

Não há nada de mais incerto e de mais frágil do que as amizades humanas. Para formá-las é preciso anos e, algumas vezes, basta um momento para destruí-las. E o que foi destruído em um instante não será reestabelecido em um século. As amizades fundadas sobre a honra e sobre a virtude não são suscetíveis desse inconveniente.

\section{XL}

Um de meus amigos tinha o coração ressequido pelos tratamentos indignos que provava da parte de uma pessoa a quem estava ligado. Ele estava terrivelmente triste, perguntaram-lhe pela razão disso: preservou o silêncio. Ele me confiou que iria se afastar definitivamente das suas relações e viver no mais intenso recolhimento. Respondi-lhe que não era esse o remédio. Vedes a todos, lhe disse, exceto a pessoa em questão, e estareis em breve tranquilo e feliz.

\section{XLI}

É insustentável viver sob um mesmo teto com pessoas em relação às quais é preciso sempre estar atento, sempre desconfiado, sempre com a guarda levantada: seria a mesma coisa passar a vida no bosque em meio a lobos e javalis.

\section{XLII}

Ofenderam-me cruelmente no fundo do meu coração e me ofendem todos os dias. Porém, Deus não permita que eu me entregue a desejos de vingança! Sinto que ainda farei bem àqueles que me fizeram e que me fazem tanto mal. Estaria mesmo mais disposto a fazer avanços do que a exigir satisfações, se acreditasse relembrá-los dos sentimentos de justiça e de amizade. Porém, perdoei tantas vezes, me precavi tão frequentemente sem sucesso que não tenho mais coragem para renovar diligências que me degradariam em pura perda. ${ }^{23}$

\section{XLIII}

Qual o caráter mais difícil de ser corrigido do que aquele de uma pessoa cuja imaginação é caprichosa e bizarra, cujo coração é altivo e imperioso, cuja vontade é dura e

23 Villenave escreve em nota que "Todo o caráter de Rousseau está traçado aqui em poucas linhas". (ROUSSEAU, 1826, p. 40). 
obstinada, cujos sentimentos são baixos e interessados! Um caráter como esse não fará jamais senão a infelicidade da pessoa dotada dele e o desespero daqueles que se interessam por ela.

\section{XLIV}

Não há verdadeira beatitude a não ser na paz interior da alma, e só se pode gozar dessa paz pela virtude.

\section{XLV}

Quando verdes alguém audacioso e servil digais, sem temor de vos enganar, que essa pessoa é viciosa. E, quando verdes alguém modesto e firme digais, com a mesma segurança, que é virtuoso.

\section{XLVI}

As aflições do tempo presente seriam de pouca monta se elas não nos recordassem a lembrança dos prazeres do tempo passado. Nós só nos queixamos do que é porque lamentamos o que não é mais.

\section{XLVII}

Há dois tipos de ciúme: um é delicado e só o temos porque não nos estimamos suficientemente. O outro é grosseiro e só o temos porque não estimamos suficientemente a pessoa amada: este é uma injúria, o primeiro é uma prova de apego.

\section{XLVIII}

Talvez o meio mais seguro e mais eficaz para acalmar uma grande dor é entregar-se a ela sem resistência.

\section{XLIX}

O melhor de todos os hábitos seria não contrair nenhum, sendo absolutamente independente e separado de tudo. Há somente o homem esclarecido, sábio e corajoso para poder adquirir esse império sobre si mesmo.

\section{$\mathbf{L}$}

Quanto mais se tem paixões, menos se é livre. Elas fazem com que nasçam as necessidades e estas sempre estão acompanhadas do desejo de satisfazê-las.

\section{LI}

Temos três tipos de vínculos:

Os primeiros, urdidos pela natureza, são inevitáveis: tal é a submissão de um filho ao seu pai.

Os segundos dependem da sorte, seja por merecimento ou não. Deles é permitido procurar se desfazer: tal é a pobreza, etc.

Os terceiros provêm de nossas ligações e de nossos engajamentos. Se a honra e as leis consagraram esses engajamentos é preciso se submeter às correntes impostas por elas: tal é o casamento, etc., etc. 
Porém, caso sejam engajamentos inúteis ou prejudiciais, aos quais a complacência e a boa-fé exageradas deram lugar, não temos nada melhor a fazer senão sacrificá-los à liberdade, e subtrairmo-nos absolutamente e sem retorno aos caprichos, à bizarrice, à falsidade e à ingratidão de outrem.

\section{LII}

Fala-se bem somente quando se sente o que é dito.

A natureza colocou no sentimento uma persuasão que as palavras não operam em absoluto e que a arte não poderia imitar.

Não há nada de verdadeiro e de expressivo a não ser o que parte do coração: podese vê-lo e escutá-lo mesmo sem a ajuda da voz e das orelhas.

\section{LIII}

De todas as virtudes, a mais admirável é o perdão das injúrias quando a vingança só depende de nós.

Tem-se uma alma generosa somente à medida em que sabemos desprezar o que ordinariamente produz a indignação ou, ao menos, dar a isso somente uma leve atenção.

\section{LIV}

O que é um impertinente? É um tolo tão repleto de si mesmo que considera os outros como nada.

\section{LV}

Quantas pessoas profanam o nome e o uso da amizade! Para uns, é somente a arte da mentira e do interesse. Para outros, um estratagema para alcançar mais seguramente os seus objetivos.

Vale infinitamente mais estar sozinho e isolado do que abrir a sua alma para tais amigos.

\section{LVI}

Para conservar um amigo é preciso tornar a si mesmo capaz de sê-lo.

Uma pessoa que relaciona tudo a ela, que ama somente as coisas relativas à sua conveniência particular, deve renunciar às doçuras e às vantagens da amizade.

\section{LVII}

Há tão somente sentimentos puros e honestos que possam formar os laços de amizade, mas o interesse os desata.

\section{LVIII}

Ter uma exagerada boa opinião de si é uma pequeneza vergonhosa que cedo ou tarde traz infelicidade.

\section{LIX}

Não é exercendo o império sobre os outros, mas ao dominar a si mesmo que se pode unicamente lisonjear-se por ter alcançado a felicidade. 


\section{LX}

O nascimento e as dignidades são títulos vãos que a sorte propicia. É pelos sentimentos que se deve ser nobre e grande. Somente a virtude merece a admiração e o respeito dos homens.

\section{LXI}

O casamento é o vínculo mais geral e o mais extenso da sociedade, porém é muito necessário que seja sempre aquele responsável por unir mais sinceramente um homem a uma mulher.

\section{LXII}

As pessoas mais inconstantes se orgulham, por vezes, de uma obstinação a toda prova, mas sua ligeireza e sua teimosia comprovam igualmente a sua fraqueza.

\section{LXIII}

Nada é comumente mais difícil do que engajar o amor-próprio a uma empreitada que de início se recusou a realizar.

\section{LXIV}

Há pessoas que preferem arriscar tudo e perder tudo pelo orgulho do que reconhecer as suas falhas e se retratar com prudência e simplicidade.

\section{LXV}

Um homem sábio está igualmente afastado da fraqueza que acredita sem discernimento e do pirronismo que transforma o não acreditar em nada em um mérito lastimável.

\section{LXVI}

É pelas obras que conhecemos o caráter. Tenta-se em vão me dizer que se tem o coração excelente, quando não vejo nem o candor que o caracteriza, nem a complacência que lhe é um atributo, nem algum desses movimentos tão expressivos do sentimento que procura agradar e que teme ofender. Procura-se inutilmente afetar essas ternas impressões da alma quando não são sentidas. E somente os imbecis são por muito tempo enganados pela dissimulação e pela falsidade.

\section{LXVII}

Não devemos jamais achar ruim que alguém não tenha gosto por nós. Há simpatias e antipatias naturais experimentadas por todos. Vê-se uma pessoa e, sem saber quais são as qualidades de seu espírito e de seu coração, sente-se inclinação ou repugnância em ligar-se a ela. Seria bem difícil justificar a si mesmo essa atração ou essa distância.

Porém, nada deve nos impedir de observar, ao menos quanto àqueles em relação aos quais não nos sentimos dispostos a gostar, o que os deveres comuns de humanidade e uma educação honesta exigem de todo mundo. É preciso se manter aí e nada seria tão criminoso e monstruoso quanto testemunhar a essas pessoas sentimentos que não temos no coração, e lhes iludir por meio de aparências enganosas. 


\section{LXVIII}

Se prestássemos seriamente atenção no caráter da maior parte dos homens e mulheres notaríamos facilmente que as pessoas que se admiram com mais facilidade são as menos afetadas pelos sentimentos com os quais as supomos dotadas.

\section{LXIX}

Não há ninguém que não tenha falhas, mas elas são desculpáveis quando ao menos são compensadas por algumas virtudes.

\section{LXX}

Por que nos afastamos frequentemente do alvo que temos em vista? É porque não comparamos os meios e o fim a que nos propomos. Tomamos uma rota ruim e um orgulho obstinado impede de tomar o caminho correto. Deseja-se que tudo se curvasse sob o império absoluto de um humor altivo e imperioso. Os acontecimentos produzem enfim humilhação e arrependimento, porém não há mais tempo.

\section{LXXI}

A escravidão mais dura é certamente aquela de uma paixão em relação à qual se deseja desembaraçar, mas não se pode.

\section{LXXII}

O verdadeiro amigo oferece seu coração sem reserva, sem condição e unicamente porque ama. Ele tem sinceridade, delicadeza, transportes e fidelidade de sentimento.

O falso amigo só ama relativamente ao seu próprio interesse e, caso a cupidez o aconselhe, torna-se ingrato e traiçoeiro.

\section{LXXIII}

Quanto mais sentimentos se tem, mais percebe-se como são encontrados apenas raramente alhures. A comparação feita de si em relação aos outros é um amor-próprio razoável e necessário que ressarce um pouco o que se sente na amizade. É uma espécie de consolação, quando estamos aflitos, encontrar apenas indiferença por parte daqueles cujos corações tínhamos direitos bem fundados.

\section{LXXIV}

Tudo o que seduz pelo exterior não passa frequentemente de uma careta perigosa e funesta. A exterioridade enganosa da probidade, da amizade e do apego são semelhantes a esses leves vapores que aparecem sobre as colinas imediatamente antes da aurora e que os primeiros raios de luz dissipam inteiramente. Não encontramos mais do que uma rocha dura e seca onde antes estava coberto por vapores.

\section{LXXV}

Tentou-se em vão disfarçar seus objetivos e intenções secretos, a máscara cai cedo ou tarde. A causa se manifesta pelos efeitos, um caráter imitado se desmente, enfim, porque ele não tem esses sintomas verdadeiros que são uma dádiva preciosa da natureza. 


\section{LXXVI}

Não me fiarei mais nem na aparência nem na fala dos homens: fui muito indignamente enganado por eles. Aprenderei, por uma longa experiência e pelo exame mais refletido a quem poderei seguramente oferecer toda minha amizade e toda a minha confiança. E quando tiver descoberto esse precioso tesouro começarei a ser verdadeiramente feliz. ${ }^{24}$

\section{LXXVII}

Os zelos oferecidos com o objetivo de agradar alguém de quem não gostamos são sempre esforços inúteis. Porém, quando gostamos, agradamos sem dificuldades e sem embaraço.

\section{Fragmentos diversos}

$1^{25}$

Não desejastes em absoluto serem meus protetor[es], meus mecenas, mas meus consoladores e meus verdadeiros amigos; e eu não vos dirigi em absoluto louvores, mas vos amei ternamente. ${ }^{26}$

Sr. Marechal e Madame Marechala, recebei com bondade esta homenagem de meu coração e possam meus escritos, vencedores do tempo, transmitirem a outras eras esse monumento do meu respeito e da minha dedicação a vós. ${ }^{27}$

\section{2}

Antes de me afastar do público, como faço agora, junto ao qual suspirava durante muitos anos, desejei oferecer-lhe uma coletânea completa e correta dos meus escritos que foram acolhidos por ele separadamente, esperando que deseje ainda agora acolhê-los reunidos e corrigidos dessa multidão de erros e de contrassensos que pululam em todas as edições feitas até aqui, por diversos editores, e que não deixaram de se esgotar com facilidade. É a primeira edição da qual participei, ela será a última, contém tudo o que me restava de manuscritos apresentáveis e como só a faço pousando a pluma...

\section{3}

Dispenso os leitores ou antes a mim mesmo dos ternos versos que me escaparam outrora e em relação aos quais me envergonho hoje. Pois, além de serem lições ruins para

\footnotetext{
24 Villenave escreve como "Rousseau não pôde encontrar esse tesouro sempre procurado, e que foi a necessidade, o tormento e o erro de sua vida" (ROUSSEAU, 1826, p. 58). [N.T.].

25 A mudança da numeração romana para a cardinal foi feita pela edição da Gallimard e é seguida por mim. [N.T.].

${ }^{26}$ Como é indicado em nota na edição da Pléiade (1964, Tomo II, p. 1956, Nota 1 da p. 1320), estes primeiros fragmentos, talvez até o sexto, provavelmente estão ligados ao projeto de edição geral das obras de Rousseau pensado por ele em 1765. [N.T.].

${ }^{27}$ Rousseau conheceu o senhor e a senhora Luxemburgo em 1759, tendo vivido em uma causa fornecida por eles em Montmorency enquanto o lugar onde moraria, em Mont-Louis, estava sendo reformado. Eles foram considerados por Rousseau como bons amigos. [N.T.].
} 
oferecer aos jovens que talvez lerão esses escritos, convém somente a corações corrompidos ousar na idade da razão fazer alarde dos desregramentos de sua juventude.

\section{4}

Não chamo essa coletânea de minhas obras porque as obras de um homem não são as coisas que diz, mas as que faz, e infelizmente estou bem distante de fazer um livro das minhas.

\section{5}

\section{Para a grande edição}

1 - Semelhante a esses frutos comidos por um inseto que são dourados à vista, perfumados ao odor e que lisonjeariam menos os sentidos se o coração fosse mais são.

2 - Como esses campos tão ricamente ornamentados nos quais a abundância de flores anuncia uma colheita ruim.

\section{6}

Como o estado do homem de letras, antes tão honroso, está aviltado aos olhos do povo desde que viu de perto os seus participantes. O nome de poeta, antes venerável e sagrado é um[a] injúria em nossos tempos, e um homem desejoso de conservar algum tipo de dignidade dificilmente ousaria confessar-se autor. De onde nasce esse desprezo e essa ignomínia? Oh verdade, quando nosso interesse não for nada diante de ti, o que será do orgulho literário? $\mathrm{O}$ que o povo pode pensar de todas essas academias observando o que se passa naquelas ao seu alcance? ${ }^{28}$ Ele vê com surpresa bandos de imbecis tornarem-se na província assuntos acadêmicos e as honras literárias prodigalizadas aos imbecis. ${ }^{29}$

Quando o vulgo vê extrair de seu seio tantos assuntos acadêmicos, quando ele aprende a respeito de quantas pesquisas frívolas são conduzidas por essas sociedades autorizadas pelo favor do príncipe, quando tantas assembleias de homens de letras lhes oferece com dificuldade alguns homens sensatos. ${ }^{30}$

\section{7}

Se é preciso sociedades literárias, questão que não pretendo resolver e a qual não desejo levantar. É certo ao menos que elas não poderiam ser em número excessivamente pequeno para a honra ${ }^{31}$ das letras e para o progresso das ciências.

\section{8}

De que servem tantas academias abertas ao pequeno número daqueles que as honram? Menos para distinguir esses grandes homens do que para dar-lhes iguais. São rebaixados quando tantos talentos fracos são elevados ao seu lado e o verdadeiro mérito,

\footnotetext{
${ }^{28}$ Nesta frase e nas duas anteriores, no original, não aparece o ponto de interrogação. [N.T.].

29 'Imbecis' aparece riscado no manuscrito. Nota traduzida da edição da Pléiade (doravante sinalizada N.P.).

30 A edição da Pléiade indica pertinentemente em nota como o assunto tratado pelos fragmentos 6, 7, 8 e 9 parecem ligar-se a preocupações contemporâneas ao Discurso sobre as ciências e as artes, de 1750 (1964, Tomo II, p. 1956, Nota da p. 1321). Note-se ainda como, após a publicação do chamado primeiro Discurso, Rousseau respondeu a várias tentativas de refutação de sua tese, conforme a qual o avanço das ciências e das artes não tiveram uma influência positiva na moral dos povos. [N.T.].

31 A primeira redação aparece riscada: "ir utilmente aos seus fins". [N.P.].
} 
esquecido ou confundido entre a multidão, se indigna ao ver prodigarem ao vulgo um prêmio devido unicamente a ele.

\section{9}

A sorte reúne três homens letrados em uma pequena cidade: rapidamente erige-se uma Academia de vinte ou trinta membros dos quais aqueles três são toda a substância. Entretanto, esses letrados morrem, a Academia subsiste esvaziada igualmente de espírito e de saber e não faltam lá os trinta sábios mais do que os dez generais que faltavam em Atenas. ${ }^{32}$

\section{0}

Essa linguagem efeminada, pueril, áspera, desprovida de calor e de força, essa trama de frases rebuscadas, esses floreios extravagantes e bizarros que eram tomados por espírito, e esse tom vil de zombaria que profanava os assuntos mais graves e tornava até mesmo a razão ridícula. ${ }^{33}$

\section{1}

Que diferença em relação aos nossos autores, incessantemente obrigados a louvar em voz alta aquilo que criticam em voz baixa, a pensar de uma forma e falar de outra.

\section{2}

Estilo impetuoso e cortado. Frases curtas, nunca máximas.

13

Afinal, além de ter mais do que é físico na constituição de nossas almas, há bastante diferença entre o que é o espírito de um homem ao sair das mãos da natureza e o que pode se tornar pelo hábito, pela educação e por seus preconceitos. ${ }^{34}$

\section{4}

A moral tem uma grande influência sobre o físico e muda, algumas vezes, até os traços do semblante. Havia mais sentimento e beleza nos semblantes dos gregos antigos do que nos de hoje em dia, há mais astúcia e menos grandeza nas fisionomias dos romanos modernos do que naquelas dos antigos. ${ }^{35}$

15

A vingança, diz Platão, é igualmente nociva ao ofensor e ao ofendido. Ao primeiro porque é escravo de sua paixão, ao outro porque é a vítima. ${ }^{36}$

\footnotetext{
${ }^{32}$ Em seguida, pode-se ler essas palavras riscadas: "Com o que se ocupa uma sociedade assim? Com pequenos versos galantes os quais Cotin recusou a autoria, a resolver alguma [ ] em honra das damas, que não teve a coragem de percorrer esses memorandos insípidos. [N.P.].

${ }^{33}$ Esse fragmento está presente no verso de uma folha rasgada. $\mathrm{Na}$ frente da folha, encontra-se o esboço de uma carta ao senhor Philopolis, redigida no outono de 1755. [N.P.].

${ }^{34}$ Esse é um tema caro a Rousseau, o da relação entre o registro da natureza, do que é universal e, de outro lado, aquele da cultura, da contingência e, portanto, da variabilidade. [N.T.].

35 A articulação entre o campo da moral e o sensível é explorada por Denis Diderot no texto Carta sobre os cegos para uso dos que veem, de 1749. [N.T.].

36 A referência deve ser do diálogo platônico intitulado Górgias. [N.P.].
} 
O homem é o mais nobre dos seres criados, o homem é a glória da terra na qual habita. Se Deus se compraz com alguma de suas obras é certamente com o gênero humano, pois tudo em nós que é da natureza é admirável; é apenas por sua própria obra que o homem se desfigurou.

\section{Reflexões}

Quereis conhecer o interior de um homem que se escamoteia? Peça por um conselho.

18

Cada um, diz um autor célebre, odeia o lowvor quando o acredita falso. Ele se engana, muitos amam o louvor menos como uma verdade lisonjeira do que como um signo do desejo que se tem de agradar, como um ato da dependência em que alguém se coloca diante deles. Pouco se importam caso haja mentira contanto que os lisonjeiem. A baixeza dos louvores oferecidos a eles compensa a verdade. ${ }^{37}$

Existe essa diferença entre o ciúme e a emulação: a emulação tende a nos elevar ao nível dos outros, e o ciúme rebaixa os outros ao nosso nível.

\section{0}

Entre nós é o corpo que anda, entre os orientais é a imaginação. Nossas caminhadas se ligam à necessidade de agitar nossas fibras rígidas em busca de novos objetos. Entre eles, o movimento do cérebro supre aquele da pessoa, permanecem imóveis e o universo caminha diante deles.

\section{1}

Os seres imortais e sensíveis possuem uma maneira de existir da qual não temos ideia e sobre a qual não poderíamos raciocinar. Pois, em relação a nós, a sensibilidade se liga ao desejo de conservação. O estado natural de um ser mortal, tal como o homem, capaz de sentir prazer e dor é o de se comprazer com o sentimento de sua existência, o de sentir com prazer aquilo que tende a conservá-lo e sentir dor em relação àquilo que tende a destruí-lo: é nesse estado natural e simples que é preciso procurar a fonte de nossas paixões.

Engana-se quem acredita que a primeira é o desejo de ser feliz. A ideia de felicidade é muito composta, a felicidade é um estado permanente cujo apetite depende da medida de nossos conhecimentos, enquanto nossas paixões nascem de um sentimento atual independente de nossas luzes. O desenvolvimento é feito com a ajuda da razão, mas o princípio existia antes dela. Já disse qual é então esse princípio, o desejo de existir. Tudo o que parece estender ou reforçar nossa existência nos lisonjeia, tudo o que parece destruí-la ou estreitá-la nos aflige: essa é a fonte primitiva de todas as nossas paixões.

${ }^{37}$ Pode-se ler, riscado, "Você me adula, mas me agrada". [N.P.]. 
Essa medida de existência ou, para falar mais propriamente, de vida, não é sempre a mesma, ela tem para nós uma certa latitude, é suscetível de crescimento ou de diminuição. Ela está no sentimento que a aprecia, mas esse próprio sentimento é passivo, depende de muitas coisas: dos sentidos, da imaginação, da memória, do entendimento, mesmo o hábito a afeta e a modifica, mas nada a afeta a não ser pela relação com nossa existência ou pelo julgamento que essa afeição nos faz carregar.

\section{2}

Verter flores e lágrimas sobre vossas honráveis cinzas. ${ }^{38}$

Ela tinha muito espírito sem se afobar em mostrá-lo. Ele era por demais sólido para as pessoas frívolas, por demais fino para os grandes raciocinadores. O que ela dizia era por demais justo para os primeiros e por demais delicado para os outros.

Porém, sua doçura não era uma fraqueza, era uma virtude. Ela sabia como ser firme sem ser obstinada, a uma só vez repleta de sensatez e de complacência. Sua vontade cedia a todo mundo, seu julgamento cedia tão somente à razão.

\section{3}

Deixai essa terra infeliz; passai, alma pura, para a estadia da paz eterna. Mulher jovem e virtuosa, não estáveis em seu lugar aqui embaixo, estáveis com pressa para satisfazer os deveres de vosso estado a fim de poder deixar a vida após ter merecido o prêmio por isso. Ide, na flor da idade, procurar a recompensa das grandes virtudes. Porém, deixai $\mathrm{a}^{39}$ terna amizade...

O caráter da Isabelle era mais do que modesto, era simples, ela não ostentava seu mérito e ele era pouco conhecido. Outros puderam vê-la como menos amável justamente por aquilo que deveria fazer com que fosse mais amada. Ela tinha talentos, isso era conhecido, porém ela mesma fazia tão pouco caso deles que se era tentado a tomá-la literalmente. Aqueles que penetravam para além viam nela qualidades mais preciosas, sabiam bem render-lhe o tributo de estima que lhe era devido.

\section{4}

Que pena! Poucos a viram e ninguém irá revê-la.

\section{5}

A maior parte dos homens, meu caro Paulino, murmuram contra a natureza por terlhes ofertado dias tão limitados e contra o tempo que corre em tal velocidade que, com exceção de um número bem pequeno, todos os outros passam a sua vida a se preparar para viver. Essas queixas não são somente, como se pensa, do povo com espírito vulgar, viu-se mesmo grandes homens ousarem repeti-las. A arte é longa, dizem os médicos, e a vida é curta. Aristóteles reprova a natureza de modo pouco conveniente a um sábio quando a acusa de ter prodigalizado séculos de vida a animais vis enquanto o homem, destinado a grandes coisas, tem o curso de sua vida limitado a um número tão pequeno de anos. Ele não deveria

\footnotetext{
${ }^{38}$ Charles Guyot, responsável pelas notas referentes à Miscelanea de literatura e de moral, sugere que este fragmento e talvez os dois seguintes se referem a Isabelle Guyenet, falecida durante o parto, em 1767. (1963, Tomo II, p. 1957. Nota I da p. 1325).

39 Onde se lê "a mais terna", a palavra "mais" aparece riscada no manuscrito. [N.P.].
} 
dizer que temos pouco tempo, mas que o perdemos muito, pois acharíamos nossa vida suficientemente longa para fazer coisas grandiosas se soubéssemos empregá-la bem. Porém, passando-a em meio ao luxo e à ociosidade, sem fazer-lhe nenhum uso útil não é nem um pouco impressionante que antes de ter percebido sua duração sintamos o seu fim. Nossa vida é por demais curta, é verdade, não por culpa da natureza, mas por nossa culpa, ela é um bem em relação ao qual somos mais pródigos do que pobres. Uma sábia economia pode conservar e fazer valer uma fonte módica ${ }^{40}$ enquanto que riquezas imensas perecem entre as mãos de um dissipador. A mesma coisa acontece com o emprego do tempo, e aquele a nós ofertado é suficiente para muitas coisas por quem quer que saiba usá-lo bem.

Por qual motivo então reclamamos da natureza? Saibamos aproveitar da vida a consideraremos suficientemente longa.

E um quarto de nossa vida não é vivido por nós. ${ }^{41}$

\section{6}

O que você me disse, meu jovem? Que estou alarmado por você, que lamento por ti! Você teme amar, então você ama, esse temor somente aparece após o mal. Porém, quando se ama

tememos amar. ${ }^{42}$

não. A primeira expectativa de amor seduz mais do que amedronta, sem examinar o que sentimos entregamo-nos a ele. Quanto mais esses transportes são doces, menos procuramos conhecê-los, por medo de sermos obrigados a vencê-los após temo-los conhecido. Assim, você não pode dar conta a si mesmo do estado do teu coração: ele não teme, nem espera: está inquieto. Sua inocência ingênua desejaria esclarecer-se sobre seus verdadeiros sentimentos. Você veio consultar um amigo da verdade a quem as paixões não são desconhecidas, você não teme perturbar seu repouso para assegurar o teu. Jovem insensato, o que você me pede? É preciso que eu me desgarre para te conduzir e que aqueça meu sangue, já meio gélido, com imagens perigosas as quais jamais se contempla impunemente? Mas quê, eu sinto demasiadamente que ao procurar seus traços apagados pela idade renovo em mim a impressão charmosa delas e, para atender aos teus desejos indiscretos, talvez ${ }^{43}$ ceda à minha inclinação mais do que à tua inconveniência.

Aproveite ao menos dos perigos aos quais você me expõe $e^{44}$ e torne-se sábio por meio da minha experiência.

Fui feliz.

Oh, minha criança, eu amava, e minha felicidade começava onde terminava os meus prazeres.

\section{7}

Menos descontente em relação àquilo que te devolvi do que com aquilo que, em absoluto, eu não te pedi mais.

\footnotetext{
${ }^{40}$ Lê-se no manuscrito original, riscado, "uma bem medíocre". [N.P.].

${ }^{41}$ Aparece na parte de baixo da página: "a metade da vida". [N.P.].

${ }^{42}$ Lề-se no manuscrito original, riscado, "talvez, também, você não ame em absoluto". [N.P.].

43 Aparece no manuscrito original, riscado, "a despeito de mim mesmo". [N.P.].

${ }^{44}$ Aparece no manuscrito original, riscado, "perigos que você me faz correr, e males os quais você faz com que me lembre". [N.P.].
} 
Do sábio. Ensaios de Moral: XII p. $8{ }^{45}$

A vida cristã, sendo oposta à torrente da natureza, quem não resiste em absoluto a essa torrente é necessariamente arrastado por ela. Basta faltar força para que logo falte virtude e tornar-se por fraqueza tão infeliz quanto a maior parte dos homens.

Esses primeiros filósofos eram virtuosos, eu o consinto, eram mesmo muito mais do que os nossos que são, no entanto, bem mais sábios do que nenhum dos antigos jamais o foi.

\section{0}

Assim, aquele que perdoa podendo punir reúne os prazeres da vingança com os da clemência. Porém, aquele que pune não os reúne.

\section{1}

Exceto que o passado não nos interessa mais senão pelas induções que fazemos quanto ao futuro.

\section{$32^{46}$}

O homem é levado pela natureza a seguir seus apetites, esse é seu primeiro princípio ativo, partilhado por todos os animais. O sentimento que se experimenta ao satisfazer um apetite se chama prazer e o sentimento contrário se chama aflição ou dor.

A continuidade de nosso ser faz com que distingamos nossos apetites conforme aqueles presentes, passados e futuros. Os primeiros são os únicos em relação aos quais temos o sentimento atual, os segundos agem sobre nós somente pela memória e os terceiros apenas pela previsão.

Chamo de prazeres concordantes aqueles que se associam uns com os outros e que um mesmo indivíduo pode experimentar. Chamo de prazeres discordantes aqueles que são incompatíveis e se excluem mutuamente. Faço a mesma distinção com as dores.

A concordância ou discordância dos prazeres e das dores é simultânea ou sucessiva. A primeira é a dos apetites que podemos ou não satisfazer. A segunda é daqueles que se associam ou se excluem em tempos diferentes.

É duvidoso caso o animal possa ter muitos prazeres verdadeiramente simultâneos. Que se possa, por exemplo, atribuir a uma só vez o sentido da vista a objetos encantadores e o do paladar a alimentos deliciosos sem que uma dessas sensações ${ }^{47}$ nos distraia da outra; porém, ainda mais duvidoso é que se possa verdadeiramente reunir ao mesmo tempo dois sentimentos opostos como um verdadeiro prazer e uma verdadeira dor.

Digo que essas questões são duvidosas, pois não poderíamos resolvê-las pela experiência, visto a multidão e a inconcebível rapidez dos instantes nos quais nossa atenção se divide entre duas ou mais sensações que nos atingem ao mesmo tempo, para atentar-se

\footnotetext{
${ }^{45}$ Tirado do texto de Pierre Nicole intitulado Ensaios sobre moralidade. [N.P.].

${ }^{46} \mathrm{Na}$ marca d'água do papel onde está escrito este fragmento, pode-se ler a data 1759. [N.P.].

47 Acima, no espaço entre as linhas, pode-se ler: "digo a mesma coisa das aflições". [N.P.].
} 
sucessivamente às suas impressões diversas, e que nos impede de distinguir se o seu efeito é sucessivo ou simultâneo.

Quanto aos prazeres sucessivos, parece que todos o que a natureza humana em geral é capaz de experimentar podem ser provados por cada homem em particular. Porém, essa verdade precisa de distinções, pois os apetites comuns à espécie não deixam de variar muito entre os indivíduos. Nem todos têm os mesmos gostos em todas as coisas, nem os mesmos graus de sensibilidade. De sorte que a alguém pode causar nojo aquilo mesmo [que] agrada a um outro, e certo prazer capaz de agradar alguém por sua delicadeza é, precisamente por isso, insípido a um outro cujos sentidos são mais grosseiros.

Há apetites, gostos de idade, de sexo, de temperamento, de situação e de hábito sobre os quais não se deve disputar porque eles se ligam a certas modificações de nosso ser as quais não dependem em absoluto de nós e que não são as mesmas em todos os indivíduos nem em cada indivíduo em todos os tempos. ${ }^{48}$

Há prazeres sensuais mais ou menos duráveis. Há os que são desgastados pelo hábito, outros que lhe resistem, outros que o hábito enfraquece a intensidade, mas que ele transforma em verdadeiras necessidades, de sorte que sem estar lisonjeado pelo seu gozo fica-se atormentado pela sua privação.

\section{$33^{49}$}

Lede, Senhor, os diálogos de Platão e percebereis que fazeis o papel do sofista orgulhoso e vosso adversário o de Sócrates. Ele vos esmagaria modestamente com argumentos terríveis aos quais responderíeis altivamente com injúrias no lugar de razões.

\section{4}

Acredito, sem ser um grande profeta, poder vos predizer facilmente a sorte a que vos preparais. Perecereis como um desatinado pelo ferro ${ }^{50}$ do melhor de vossos amigos, ou sereis visto algum dia como vil e penitente tardio entre os braços de um monge, ${ }^{51}$ lutando contra $o$ medo da morte e do diabo.

\section{5}

Por mais que tivesse esperança de me pôr de modo mais confortável, limitar-me-ia de bom grado ao necessário para alcançar para minha família, um dia, mais abundantemente o confortável, porém com dificuldade posso ganhar com o que sustentá-la. O pouco que economizaria por semana não faria em vinte anos uma poupança suficiente para me fornecer um rendimento concreto. Tenho necessidade disso para me alegrar ou me consolar, ${ }^{52}$ para animar minha coragem, minhas forças e suportar sem me queixar de um trabalho contínuo cujo desfecho se dará apenas com o fim da minha vida. Domingo vou à taberna com a minha

\footnotetext{
48 No manuscrito, nesta passagem, existem muitas frases riscadas: "A sensualidade de uma criança limita-se a comer açúcar e ela não considera como soberano bem senão um lugar abundante e fértil. Não se passa a mesma coisa com vinte anos, a sensualidade de uma criança não é mais aquela de um jovem, e os gostos do jovem... aquele de um idoso não os mesmos." [N.P.].

${ }^{49}$ Charles Guyot sugere, baseado no que está escrito nos papeis onde estão os fragmentos 33, 34, 35, 38, 39, 41, 42 e 43 que eles devem datar de 1764 (1964, Tomo II, p. 1959. Nota I da p. 1330).

50 "Ferro" deve ser entendido como algum tipo de arma tal qual uma espada, uma lança ou uma flecha.

51 A palavra "capuchinho" aparece riscada. [N.P.].

${ }^{52}$ Lê-se, riscado, "de quando em quando aos domingos". [N.P.].
} 
esposa, pois não tenho condições de me elevar acima do meu estado e de me meter a corromper moças honestas ou ir a lugares perniciosos. Meu amigo, lhe diz sua esposa com um ar que me penetrou, sei bem que você, ademais, não tem vontade de fazer isso. Não, ele disse, pois dessa maneira minha família sofreria. Bebamos.

$$
36^{53}
$$

\section{A solidão}

Seres inanimados os quais preferiria à sociedade dos homens.

\section{7}

Se sob o carvalho onde repousarão as minhas cinzas.

\section{8}

No seio da superstição, onde a razão não tem nenhuma força, é preciso necessariamente que a filosofia tome um ar misterioso para se impor. Sem isso, todas as verdades que são apenas demonstrações não encontrariam nenhum sectário.

\section{9}

Sem dúvida, seria preciso dizer coisas boas, mas para dizê-las utilmente seria preciso começar por $^{54}$ se fazer escutar.

\section{0}

Os dois sexos valeriam mais, se estimariam mais e estejais certo de que o verdadeiro amor não perderia nada com isso.

\section{1}

Há quase tão somente os loucos para poderem se passar por professores de sabedoria e, nos tempos em que há uma multidão de filósofos, são sempre aqueles nos quais se vê menos sábios.

\section{2}

Oh, gregos, tranquilizai-vos. A frota ${ }^{55}$ que se aproxima em disparada e e $^{56}$ das nossas, reconheço a bandeira do invencível Aquiles. Lesbos foi tomada, ele nos traz a vitória em sua companhia. ${ }^{57}$ Os deuses vão entregar Heitor e a Frígia aos golpes desse herói.

\section{3}

Errava em densas trevas, o brilho repentino do dia me ofuscou e continua me arrebatar o dia. Meu coração languescia sem esperança. ${ }^{58}$ Tomo consciência de minha felicidade e não ouso acreditar nela.

\footnotetext{
${ }^{53}$ Charles Guyot sugere que este fragmento e o seguinte devem datar do inverno entre 1758/1759 porque estão junto com contas relativas ao padeiro desta data (1964, Tomo II, p. 1959. Nota da p. 1330).

${ }^{54}$ Lê-se, riscado, "descobrir o segredo de". [N.P.].

${ }^{55}$ Lê-se, riscado, "é uma frota amiga". [N.P.].

${ }^{56}$ Lê-se, riscado, "uma das nossas". [N.P.].

${ }^{57}$ Lê-se, riscado, "é, além disso, com os golpes desse herói que”. [N.P.].

${ }^{58}$ Lê-se, riscado, "subitamente". [N.P.].
} 
Preferência muito conveniente à ordem, pois a natureza expirante tem mais necessidade de socorro do que a natureza agitada.

\section{$45^{59}$}

Muito frequentemente esse enternecimento não é em absoluto obra da reflexão, mas tão somente da memória: ao nos rememorar a ideia de nossos males passados é responsável por fazer com que nos identifiquemos mais intensamente com aquele que sofre atualmente algo semelhante.

\section{6}

As lágrimas que se derrama durante a representação de uma tragédia interessante, assim como o sentimento interior que nos faz ter compaixão pelos infelizes têm para nós uma doçura extrema, etc., etc... $\mathrm{O}$ abade Dubos diz bastante isso, mas me parece que a razão é pouco satisfatória pela maneira com a qual pretende explicá-la: ele diz que o prazer vem da emoção, contudo, por que certas emoções são prazerosas enquanto outras não o são em absoluto, como ver um doente sofrer ou um homem sendo injustamente maltratado?

Por que a emoção causada pela piedade nos é prazerosa em certos casos e em outros, não?

A alma dificilmente se identifica com homens desprezíveis que nos causariam aborrecimento caso nos assemelhássemos a eles, e alguns males pelos quais sofrem não nos inspiram jamais uma piedade muito viva. Porém, adoramos nos colocar no lugar de um herói infeliz, que triunfa por sua coragem sobre um perseguidor bárbaro, e apresenta a nossos olhares uma virtude da qual nos apropriamos com tanto mais boa vontade quanto a própria ação nada nos custa. Se a tragédia sobre Atreu nos causa menos piedade que horror é porque Tieste é um homem fraco que sabemos ser culpado e em relação ao qual os espectadores, pouco comovidos, sentem um interesse tão somente medíocre. Porém, não testemunhamos em absoluto os riscos do virtuoso sem muitas lágrimas... porque o orgulho nos leva a nos identificar de bom grado com essa grande alma próxima da qual nos esforçamos em elevar a nossa. ${ }^{60}$

\section{Referências Bibliográficas}

ROUSSEAU, Jean-Jacques. "Cartas morais". In: Carta a Christophe de Beaumont e outros escritos sobre a religião e a moral. Org. José Oscar de Almeida Marques. São Paulo: Estação liberdade, 2005.

\footnotetext{
${ }^{59}$ Este fragmento e o seguinte mencionam a obra Reflexões críticas sobre a poesia e sobre a pintura, de JeanBaptiste Dubos, publicadas pela primeira vez em 1719. [N.T.].

${ }^{60}$ A peça mencionada deve ser aquela escrita por Crébillon intitulada Atrée et Thyeste. Esse fragmento se liga, ao menos por sua temática à Carta a d'Alembert, obra em que se discute peças teatrais de vários autores franceses e gregos. Nota do tradutor.
} 
. "Confessions". In: CEuvres Complètes. Org. Bernard Gagnebin e Marcel Raymond. Tomo I. Paris: Gallimard, 1959.

"Considérations sur le gouvernement de Pologne". In: EEurres Complètes. Org. Bernard Gagnebin e Marcel Raymond. Tomo III. Paris: Gallimard, 1964a.

"Fragments divers". In: CEuvres Complètes. Org. Bernard Gagnebin e Marcel Raymond. Tomo II. Paris: Gallimard, 1964b.

"Nouvelle Héloïse". In: CEuvres Complètes. Org. Bernard Gagnebin e Marcel Raymond. Tomo II. Paris: Gallimard, 1964c.

"Pensées d'un esprit droit, et sentiments d'un coeur vertueux". In: Euvres Complètes. Édition thématique du tricentenaire. Org. Raymond Trousson e Frédéric S. Eigeldinger. Volume 17. Genebra: Slaktine, 2012.

. "Pensées d'un esprit droit, et sentiments d'un cœur vertueux". In: Euvres Complètes. Org. Bernard Gagnebin e Marcel Raymond. Tomo II. Paris: Gallimard, 1964d.

Pensées d'un esprit droit, et sentiments d'un cour vertueux. Ouvrage inédit, imprimé sur le manuscrit autographe de l'auteur ; suivi d'un autre opuscule de Rousseau intitulé : Mcurs, Caractère. Paris : Fournier-Favreux, 1826. 